\section{Unusual hematologic disease affecting Caucasian children traveling to Southeast Asia: acquired platelet dysfunction with eosinophilia}

\author{
Anselm Chi-wai Lee \\ Children's Haematology and Cancer \\ Centre, Mount Elizabeth Hospital, \\ Singapore
}

\begin{abstract}
An 11-year-old American boy was staying with his family in Indonesia. He presented with a 5-month history of recurrent bruises and ecchymosis. A clinical diagnosis of acquired platelet dysfunction with eosinophilia was made when his full blood counts showed hypereosinophilia $\left(7.4 \times 10^{9} / \mathrm{L}\right)$ with normal platelet count and gray platelets under the microscope. The diagnosis was supported by abnormal platelet aggregation tests consistent with a storage pool disorder. The bleeding symptoms and eosinophilia resolved a month later with a full course of antihelminthic therapy. Hematologists should be aware of this unusual disease in travelers returning from the Southeast Asia.
\end{abstract}

\section{Introduction}

Acquired platelet dysfunction with eosinophilia (APDE) is usually a self-limiting bleeding disorder characterized by an insidious onset of easy bruising with petechiae in an otherwise well person. ${ }^{1}$ Hypereosinophilia is often the first clue to diagnosis, which is supported by the findings of a platelet storage pool disorder. APDE has been mainly reported from Thailand, Malaysia, and Singapore, but its true incidence has not been studied. The condition has rarely been reported elsewhere and hence travelers returning from an endemic area may present with a diagnostic challenge.

\section{Case Report}

An 11-year-old Caucasian boy presented with recurrent cutaneous bruises and ecchymosis for five months. The child's past health was only remarkable for occasional asthmatic attacks when he was small and he had no prior history of bleeding tendency or excessive swelling following vaccinations. Fifteen months ago, the family moved from the United States and lived in central Java, Indonesia. Five months before the consultation, he was noticed to have recurrent, unprovoked bruising of the skin with occasional epistaxis and gum bleeding. There were no symptoms of gastrointestinal, genitourinary, or intra-articular hemorrhage. He had not been noted to have worms in the stool although he had been treated with antihelminthics every 3 to 4 months. The family history was negative for bleeding diathesis. The child was otherwise well and continued to go to school as usual.

On examination, there were multiple bruises from 1 to $3 \mathrm{~cm}$ in maximum dimension with petechiae over the limbs, the scalp, the chest and abdominal wall. There was no mucosal bleeding, cervical lymphadenopathy, or hepatosplenomegaly. Laboratory investigations showed hemoglobin $12.8 \mathrm{~g} / \mathrm{dL}$, white cell count $14.8 \times 10^{9} / \mathrm{L}$, eosinophils $7.4 \times 10^{9} / \mathrm{L}$, platelet $223 \times 10^{9} / \mathrm{L}$, IgE $>2,000$ IU/mL Serum biochemistries, liver transaminases, prothrombin time, partial thromboplastin time, and other immunoglobulin levels were normal. No ova or parasites were found in the stool. The chest $\mathrm{x}$ ray was normal. The peripheral blood film shows prominent eosinophilia with the presence of gray platelets (Figure 1). The results of the platelet aggregation tests showed defective aggregation with collagen and epinephrine, consistent with a platelet storage pool disorder (Table 1). Thus, a diagnosis of APDE was made.

He was empirically treated with albendazole $400 \mathrm{mg}$ as single dose and a repeated dose two weeks later. All the family members were also advised to take the same treatment. The bleeding symptoms gradually subsided a month later. The absolute eosinophil counts fell to 0.67 and $0.63 \times 10^{9} / \mathrm{L}$ one and four months afterwards, respectively. Parents reported that the child remained well at one year after the last consultation.

\section{Discussion}

Acquired platelet dysfunction with eosinophilia (APDE) is a unique disease that was first and almost exclusively described in the region of Thailand, Malaysia and Singapore. ${ }^{2-4}$ The condition affects mainly patients of the pediatric age group, but adults are not spared. ${ }^{5}$ Helminthic infestation has been associated with APDE in about $50 \%$ of the cases, ${ }^{1}$ but how helminthes would explain the geographic occurrence is mysterious. The thrombocytopathic bleeding is evidenced by a prolonged bleeding time and positive Hess's test, degranulated platelets, and abnormal platelet aggregation tests consistent with a
Correspondence: Dr. Anselm Lee, Children's Haematology and Cancer Centre, Mount Elizabeth Hospital Level 4, 3 Mount Elizabeth, Singapore.

Tel. +.65.6731.2673 - Fax: +65.6235.4924.

E-mail: anselm.cw.lee@gmail.com

Key words: acquired platelet dysfunction; eosinophilia; hemorrhage; thrombocytopathy.

Conflict of interest: the autors declare that there is no conflict of interest.

Received for publication: 10 September 2011. Revision received: 3 January 2012.

Accepted for publication: 9 January 2012.

This work is licensed under a Creative Commons Attribution NonCommercial 3.0 License (CC BYNC 3.0).

(C)Copyright A.C. Lee et al., 2012

Licensee PAGEPress srl, Italy

Hematology Reports 2012; 4:e5

doi:10.4081/hr.2012.e5

platelet storage pool disorder. The platelet dysfunction is believed to be secondary to eosinophilia but raised eosinophil counts are not found in all patients.

Laosombat et al. reported from Thailand a large cohort of 168 children diagnosed with APDE. ${ }^{6}$ The majority of them presented with mild cutaneous bruises only, but $14(8 \%)$ of them had severe bleeding symptoms that necessitated platelet transfusion therapy. No mortality was reported. The bleeding manifestations resolved within 6 months of diagnosis, although $12(7 \%)$ of them had a recurrence. Lucas reported 12 pediatric cases from Sri Lanka with mild symptomatology. ${ }^{7}$ All children were treated empirically with diethylcarbamazine and mebendazole and recovered within six months. Ruiz-Saez et al. described six cases of APDE from Venezuela. ${ }^{8}$ Intestinal parasites were found in all cases and five of them harbor multiple infestations. Five of them recovered within two months after antihelminthic treatment while the bleeding manifestations persisted for 36 months in the other patient.

APDE has to be distinguished from other causes of bleeding and myeloproliferative disorders. In particular, the presence of multiple bruises in the presence of normal platelet count and coagulation screen may be confused with accidental or non-accidental injury, ${ }^{9}$ while the extreme hypereosinophilia may be suggestive of hypereosinophilic syndrome. ${ }^{10}$ A comprehensive review by a pediatric hematologist will be essential for an accurate diagnosis without embarking on distressing medical or social investigations. As the case has illustrated, the diagnosis of APDE can be reasonably reached with attention to the history, physical 
Table 1. The results of the patient's platelet aggregation tests.

\begin{tabular}{lcc}
\hline Test & Result & Normal ranges \\
ADP & $69 \%$ & $64-111 \%$ \\
Collage & $31 \%$ & $68-117 \%$ \\
\hline Epinephrine & $21 \%$ & $46-122 \%$ \\
Ristocetin & $100 \%$ & $80-115 \%$ \\
\hline Arachidonic acid & $78 \%$ & $52-110 \%$ \\
\hline
\end{tabular}

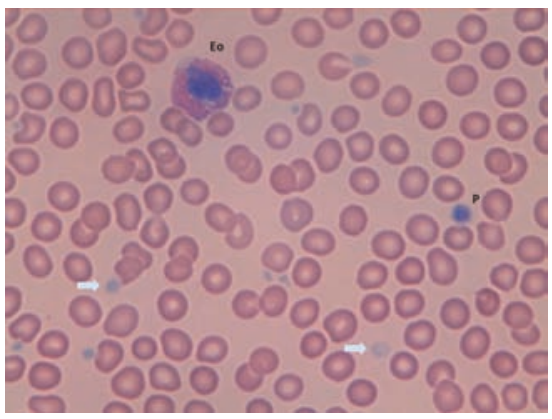

Figure 1. Photomicrograph of the blood film $(\times 100)$ showing an eosinophil of normal morphology (Eo), a platelet of normal morphology $(\mathrm{P})$, and platelets that appear pale and agranular (arrows). The latter feature is highly suggestive of thrombocytopathy and should obviate the need to measure the bleeding time.

findings, simple laboratory tests, and examination of the platelet morphology on blood smear.

Sporadic reports from the United Kingdom, ${ }^{11}$ Canada, ${ }^{12}$ and Hong Kong ${ }^{13}$ are usually imported cases from the Southeast Asia (Table 2). All five children presented with easy bruising, eosinophilia with normal platelet counts, but parasites were not found in any of them. Some of these patients had been extensively investigated before the diagnosis of APDE was made. Together with this reports, the present case is illustrative of the fact that APDE is not restricted to the indigenous population in the tropical countries and it may affect any child who has traveled to the Southeast Asia.

Table 2. Pediatric cases of acquired platelet dysfunction with eosinophilia reported from non-tropical countries.

\begin{tabular}{|c|c|c|c|c|c|}
\hline Cases & $\begin{array}{c}\text { Sex/Age } \\
\text { (year) }\end{array}$ & $\begin{array}{l}\text { Reporting } \\
\text { countries }\end{array}$ & $\begin{array}{l}\text { Countries } \\
\text { traveled }\end{array}$ & $\begin{array}{l}\text { Parasitology/ } \\
\text { Recovery }\end{array}$ & Ref \\
\hline 1 & Female/8 & United Kingdom & Malaysia & $\begin{array}{l}\text { No parasite found } \\
\text { Recovered in } 3 \text { months }\end{array}$ & 11 \\
\hline 2 & Male/5 & Canada & Malaysia & $\begin{array}{l}\text { No parasite found } \\
\text { Recovered in } 1 \text { month }\end{array}$ & 12 \\
\hline 3 & Male/6 & Canada & Malaysia & $\begin{array}{l}\text { No parasite found } \\
\text { Recovered in } 2 \text { months }\end{array}$ & 12 \\
\hline 4 & Male/4 & Hong Kong & Thailand & $\begin{array}{l}\text { No parasite found } \\
\text { Recovered in } 1 \text { month }\end{array}$ & 13 \\
\hline 5 & Female/8 & Hong Kong & Nepal & $\begin{array}{l}\text { No parasite found } \\
\text { Recovered in } 1 \text { month }\end{array}$ & 13 \\
\hline
\end{tabular}

\section{References}

1. Isarangkura P. Acquired platelet dysfunction with eosinophilia. Education Program of the IXth Congress of the International Society of Hematology Asia-Pacific Division, Bangkok, Thailand, October 24-28, 1999. Available from: http://www.ishapd. org/1999/ish1999.htm

2. Mitrakul C. Transient, spontaneous bruising with long bleeding time and normal platelet count. Am J Clin Pathol 1975;63:81-6.

3. Kueh YK. The syndrome of non-thrombocytopenic purpura with eosinophilia: an acquired platelet dysfunction. New Engl J Med 1982;306:365.

4. Chin NS, Koong PL. A study of 31 patients with easy bruising from University Hospital, Kuala Lumpur. Med J Malaysia 1990;45:325-8.

5. Lim SH, Tan CE, Agasthian T, Chew LS. Acquired platelet dysfunction with eosinophilia: review of seven adult cases. $\mathrm{J}$ Clin Pathol 1989;42:950-2.

6. Laosombat V, Wongchanchailert M, Sattayasevana B, et al. Acquired platelet dysfunction with eosinophilia in children in the south of Thailand. Platelets 2001;12: 5-14.

7. Lucas GN. Acquired platelet dysfunction with eosinophilia (APDE). Sri Lanka J Child Health 2002;31:89-90.

8. Ruiz-Sáez A, Sifontes LN, Feijoo R, et al. Platelet dysfunction-eosinophilia syndrome in parasitized Venezuelan children. Am J Trop Med Hyg 2005;73:381-5.

9. Lee AC. Bruises, blood coagulation tests and the battered child syndrome. Singapore Med J 2008;49:445-9.

10. Scheinfeld N. Fatal fulminant hypereosinophilic syndrome with a petechial rash in a 16-year-old girl. J Pediatr Hematol Oncol 2003;25:827-30.

11. Muthiah MM, Mitchell TR, Thorn CT. Acquired platelet dysfunction with eosinophilia. BMJ 1984;289:1044.

12. Poon MC, Ng SC, Coppes MJ. Acquired platelet dysfunction with eosinophilia in white children. J Pediatr 1995;126:959-61.

13. Zhou X, Ha SY, Ma SK, et al. Acquired platelet dysfunction with eosinophilia: report of two cases. Hong Kong J Paediatr 2000;5:143-5. 